\title{
Interannual variability of the bimodal distribution of summertime rainfall over Central America and tropical storm activity in the far-eastern Pacific
}

\author{
Scott Curtis* \\ Joint Center for Earth Systems Technology, University of Maryland, Baltimore County, Department of Geography, \\ NASA/Goddard Space Flight Center, Code 912, Greenbelt, Maryland 20771, USA
}

\begin{abstract}
The summer climate of southern Mexico and Central America is characterized by a midsummer drought (MSD), where rainfall is reduced by $40 \%$ in July as compared to June and September. A mid-summer reduction in the climatological number of eastern Pacific tropical cyclones has also been noted. Little is understood about the climatology and interannual variability of these minima. The present study uses a novel approach to quantify the bimodal distribution of summertime rainfall for the globe and finds that this feature of the annual cycle is most extreme over Pan America and adjacent oceans. One dominant interannual signal in this region occurs the summer before a strong winter El Niño/Southern Oscillation (ENSO). Before El Niño events the region is dry, the MSD is strong and centered over the ocean, and the mid-summer minimum in tropical cyclone frequency is most pronounced. This is significantly different from Neutral cases (non-El Niño and non-La Niña), when the MSD is weak and positioned over the land bridge. The MSD is highly variable for La Niña years, and there is not an obvious mid-summer minimum in the number of tropical cyclones.
\end{abstract}

KEY WORDS: Rainfall · Tropical storms · Summer $\cdot$ Central America $\cdot$ ENSO

Resale or republication not permitted without written consent of the publisher

\section{INTRODUCTION}

The climatology and interannual variability of summertime precipitation over Mexico and the SW United States (also referred to as the North American monsoon) has received increased attention in recent years (e.g. Adams \& Comrie 1997, Higgins et al. 1999). Applicable to this body of work, Magaña et al. (1999) described a bimodal distribution of precipitation over southern Mexico and Central America during the summer months. They showed that the mid-summer drought (MSD) is forced by the seasonal fluctuation of sea-surface temperature (SST). Regional climate studies have also noted bimodal distributions of summertime precipitation, resulting from different forcing mechanisms, in the upper Midwest of the US (Keables 1989) and at the Equator (Hartmann 1993). However, a

*E-mail: curtis@agnes.gsfc.nasa.gov globally uniform climatological analysis of intraseasonal precipitation has not been performed.

The typical evolution of precipitation anomalies over Mexico leading up to a mature El Niño is below normal rainfall during the monsoon season (Higgins et al. 1999), followed by above-normal rainfall in autumn (Ropelewski \& Halpert 1986). The 1997-1998 El Niño was a special case, as the summer drought in Mexico extended into winter (Bell et al. 1999).

Magaña et al. (1999) found that the MSD appears regardless of the phase of the El Niño/Southern Oscillation (ENSO) and that there was no concurrent relationship between the MSD and ENSO. However, summertime (June-August) rainfall over Mexico shows little correlation with ENSO during the same season but a significant correlation with the following winter (December-February) conditions (Table 1). Thus, in this study the focus is on the relationship between the summer rainy season and the state of ENSO the following winter. 
While eastern Pacific tropical storms play an important role in the North American monsoon system (eg. Higgins \& Shi 2001), extreme events can be very costly to the people of Mexico's west coast. The ratio of tropical storm rainfall to total rainfall in SW Mexico ranges from 10 to $40 \%$ (Englehart \& Douglas 2001). These values exceed $50 \%$ in the vicinity of the Baja peninsula (Rodgers et al. 2000, Englehart \& Douglas 2001).

Attempts have been made to relate the seasonal statistics of eastern Pacific tropical cyclones to ENSO. Whitney \& Hobgood (1997) found no ENSO-related impact on the number, intensity, or track length of tropical storms. Irwin \& Davis (1999) showed that storms originated about $6^{\circ}$ longitude to the west of normal during strong El Niño events. This is consistent with the findings of Englehart \& Douglas (2001), who found that tropical-storm-related rainfall at stations on Mexico's southwest coast decreased during El Niño events. However, Rodgers et al. (2000), using satellite data, showed that tropical cyclone rainfall was enhanced over the far-eastern Pacific for El Niño versus La Niña summers.

Most intraseasonal diagnostics of tropical cyclone activity have focused on the Madden Julian Oscillation (MJO), which has a 30 to $60 \mathrm{~d}$ periodicity (e.g. Maloney \& Hartmann 2000). Magaña et al. (1999) described a mid-summer minimum in the frequency of storms over the eastern Pacific warm pool as a signature of the MSD. However, questions remain as to the relationship of the bimodal nature of tropical cyclone activity to the intraseasonal rainfall variability. Also, no studies (to my knowledge) have examined the interannual variability of the bimodal distribution of eastern Pacific tropical storms.

A state-of-the-art precipitation data set will be introduced and a method will be described to quantify the bimodal nature of precipitation and number of named storms in Section 2. The mid-summer minima in precipitation over Mexico and Central America and num-

Table 1. Correlations between Mexican monsoonal rainfall $\left(95-110^{\circ} \mathrm{W}, 7.5-27.5^{\circ} \mathrm{N}\right)$ and El Niño/Southern Oscillation (ENSO) precipitation index for the prior winter DecemberFebruary [DJF(-)], concurrent summer June-August [JJA(0)], and following winter $\operatorname{DJF}(0)$

\begin{tabular}{|lrll|}
\hline \multicolumn{4}{c|}{ ENSO precipitation index } \\
& DJF(-) & JJA(0) & DJF(0) \\
\hline June-August & 0.26 & -0.02 & $-0.81^{* *}$ \\
June & -0.13 & -0.48 & -0.45 \\
July & 0.50 & -0.09 & -0.34 \\
August & 0.11 & $-0.61^{*}$ & $-0.82^{* *}$ \\
${ }^{*}$ Significance at the 5\% level & & \\
${ }^{* *}$ Significance at the 1\% level & & \\
\hline
\end{tabular}

ber of tropical storms in the far-eastern Pacific will be analyzed in terms of ENSO in Sections 3 and 4. The SST forcing mechanism will be examined in Section 5. Finally, a summary of the results and a discussion of other forcing mechanisms that may contribute to the different intraseasonal variations during El Niño, La Niña, and Neutral summers will be presented in Section 6.

\section{DATA AND METHODS}

Intraseasonal precipitation information is obtained from the Global Precipitation Climatology Project (GPCP) pentad (5 d) $2.5^{\circ}$ latitude by $2.5^{\circ}$ longitude data (Xie et al. unpubl.). This data set, spanning the period 1979 to present, is similar to the Climate Prediction Center's Merged Analysis of Precipitation (CMAP; Xie \& Arkin 1997), except that the pentad precipitation estimates are adjusted to sum to the GPCP Version 2 monthly product (Adler et al. unpubl.). The GPCP pentad product is a merger of various satellite estimates and gauge information and is of higher quality compared to individual data sources.

Weekly National Center for Environmental Prediction (NCEP) SST anomalies (Reynolds \& Smith 1994) at $1^{\circ}$ latitude by $1^{\circ}$ longitude resolution were averaged into an East Pacific warm pool index $\left(105-95^{\circ} \mathrm{W}\right.$, $\left.10-15^{\circ} \mathrm{N}\right)$.

Tropical storm and hurricane track information was downloaded from the National Hurricane Center website (http://www.nhc.noaa.gov). Storms located in the Pacific Ocean east of $110^{\circ} \mathrm{W}$ were counted once on the day they originated, and the counts were summed over $10 \mathrm{~d}$ (2 pentad) intervals from May 1-10 to October 28-November 6. This was done to ensure consistency with the GPCP data.

The ENSO precipitation index (ESPI; Curtis \& Adler 2000), a monthly measure of the zonal gradient of precipitation anomalies between the central equatorial Pacific $\left(10^{\circ} \mathrm{S}-10^{\circ} \mathrm{N}, 160^{\circ} \mathrm{E}-100^{\circ} \mathrm{W}\right)$ and the Maritime Continent $\left(10^{\circ} \mathrm{S}-10^{\circ} \mathrm{N}, 90-150^{\circ} \mathrm{E}\right)$, was used to define ENSO events. ESPI is highly correlated to traditional measures of ENSO such as the Nino 3.4; however ESPI is more closely connected to the large-scale circulation as forced by warm and cold SST events.

A simple objective method was devised for quantifying the bimodal nature of May-October precipitation and the number of tropical cyclones. The first-order harmonic $(\mathrm{FOH})$ from the normalized variance spectrum of a time series yields a sinusoidal wave with 1 peak and 1 trough. For the case of the precipitation data, if the peak (trough) is near the center of the time range, then the $\mathrm{FOH}$ represents a rainy season (dry season) (Fig. 1). The second-order harmonic (SOH) 


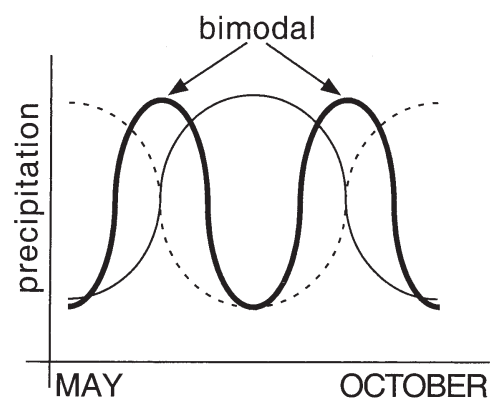

Fig. 1. Examples of harmonic models to precipitation data. Thin solid and dashed lines represent wet and dry seasons, respectively, as modeled by the first-order harmonic. Heavy solid line represents a bimodal distribution of precipitation (with a minimum centered in the middle of the season), as modeled by the second-order harmonic

yields a sinusoidal wave with 2 peaks and 2 troughs. Only in the special case where 1 of the troughs is very close to the beginning (early May) or end (late October) of the record does the $\mathrm{SOH}$ represent the midsummer minimum condition (Fig. 1). The time series of precipitation and number of tropical cyclones are actually composed of the $\mathrm{FOH}$, $\mathrm{SOH}$, and other higher-frequency oscillations. This paper is only concerned with the relative strengths of the $\mathrm{SOH}$.

\section{THE MID-SUMMER DROUGHT}

A 21 yr climatology (1979-1999) of pentad precipitation was constructed for May 1-5 to October 28-November 1. The normalized variance spectrum was computed for each grid block, and the variance

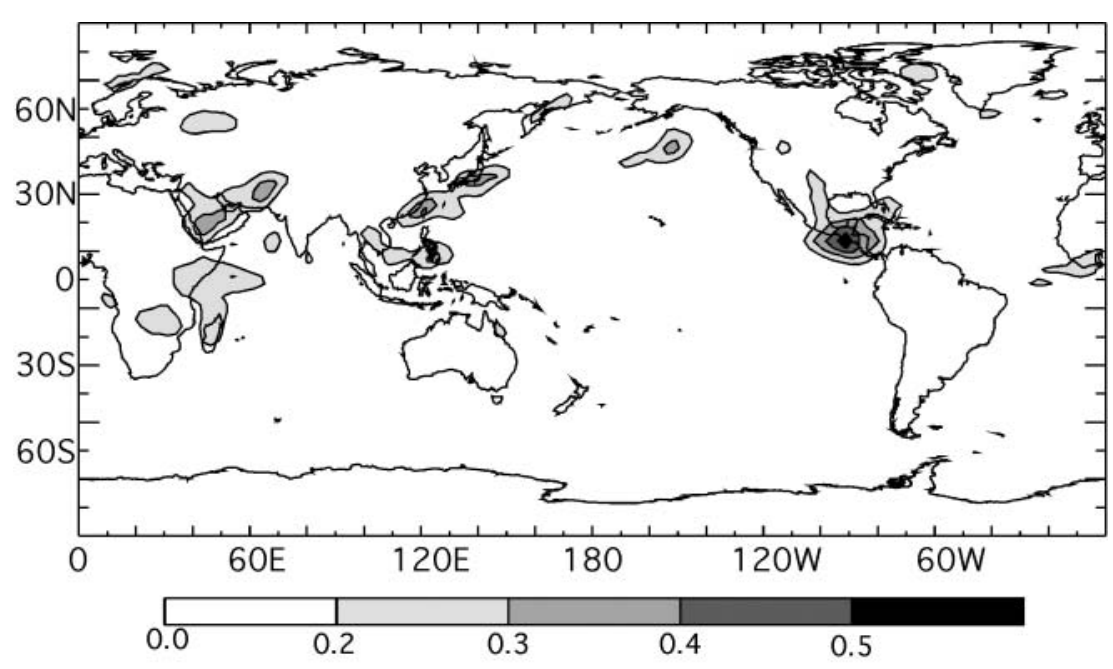

Fig. 2. Variance explained by the second-order harmonic for climatological (1979-1999) May-October global precipitation. Shading increases with the contour levels $0.2,0.3,0.4$, and 0.5 explained by the SOH was plotted (Fig. 2). Areas such as coastal China and southern Japan show some power in this mode. However, the $\mathrm{SOH}$ is strongest in the Pan American region, where the MSD has been historically observed, suggesting that the $\mathrm{SOH}$ is a good statistical model for this phenomenon of the annual cycle. The SOH explains over $30 \%$ of the variance of summertime precipitation over much of southern Mexico, Central America, and surrounding oceans, and it explains over $50 \%$ of the variance over Guatemala and El Salvador (Figs. 2 \& 3A).

Next, the summers from 1979-1999 were categorized by the ESPI value of the following December-February (DJF). El Niño summers were defined as 1982, 1986, 1989, 1991, 1992, 1994, and 1997 (average ESPI value: 0.97), La Niña summers as 1983, 1984, 1985, 1988, 1995, 1998, and 1999 (average ESPI value: -0.98), and Neutral summers as 1979, 1980, 1981, 1987, 1990, 1993, and 1996 (average ESPI value: -0.32). The same spectral analysis was performed on the 3 composites of precipitation. The $\mathrm{SOH}$ is equally strong for El Niño years (Fig. 3B) as compared to climatology (Fig. 3A), but the bulk of the values have shifted westward over the ocean. For the La Niña (Fig. 3C) and Neutral (Fig. 3D) composites the power of the $\mathrm{SOH}$ is reduced substantially. Also, in the Neutral case, values in excess of $20 \%$ are centered over land (Fig. 3D).

To test whether the differences between the El Niño composite and non-El Niño composites are significant, the power of the $\mathrm{SOH}$ for precipitation values averaged over the core of the MSD region (Fig. 3) was computed for each year. The time series of the variance explained by the $\mathrm{SOH}$ is given in Fig. 4. The La Niña years have a mean value equivalent to the climatological mean (0.20) and a large standard deviation. In fact, the year with the lowest power (1985) and the year with the highest power (1999) are La Niña years. Five out of the $7 \mathrm{El}$ Niño years have power above the mean, and 6 out of the 7 Neutral years have power below the mean. A 2tailed $t$-test shows that the El Niño years and Neutral years are significantly different at the $95 \%$ confidence level ( $t=2.4$ and $\mathrm{p}=0.033)$.

\section{THE MID-SUMMER MINIMUM IN TROPICAL CYCLONES}

In this section the number of named tropical cyclones originating to the east of $110^{\circ} \mathrm{W}$ (dashed line in Fig. 3) is ex- 


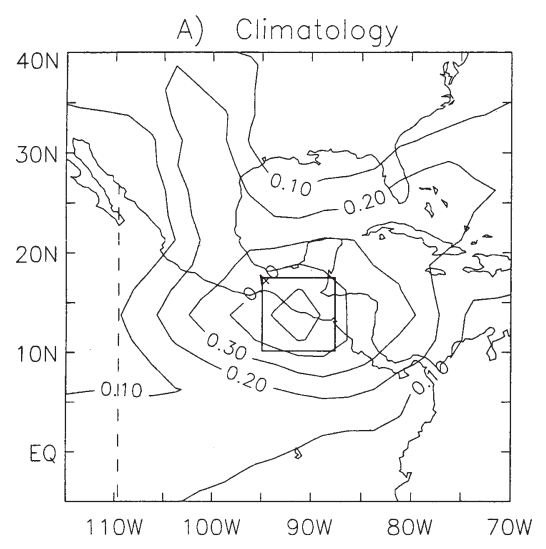

B) El Nino $(82,86,89,91,92,94,97)$
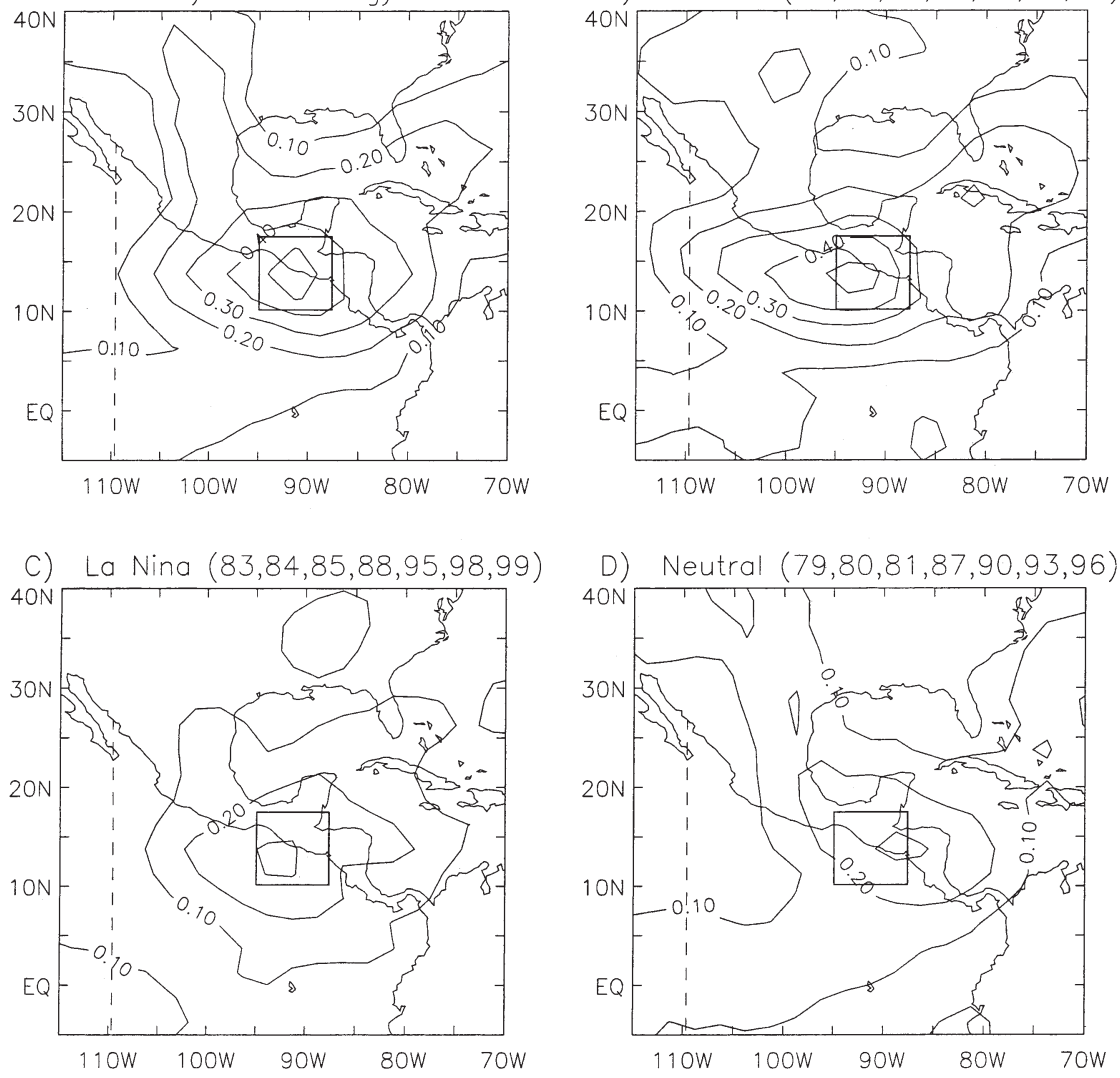

Fig. 3. Variance explained by the second-order harmonic for climatological May-October precipitation in the Pan American region. (A) 1979-1999 climatology, (B) El Niño years (1982, 1986, 1989, 1991, 1992, 1994, and 1997), (C) La Niña years (1983, 1984, 1985, 1988, 1995, 1998, and 1999), and (D) Neutral years (1979, 1980, 1981, 1987, 1990, 1993, and 1996). Boxes indicate area over which mean precipitation time series were computed for Figs. 4 \& 5. Dashed line marks the western boundary of the Pacific tropical cyclone search area

amined from May-October. Fig. 5A shows a bimodal distribution, consistent with Magaña et al.'s (1999) results. From 1979 to 1999 a relative minimum in named storms occurred in the middle of August. However, the $\mathrm{SOH}$ of the time series explains less of the variance $(23.5 \%)$ than the $\mathrm{FOH}(67.6 \%)$, suggesting that the time series of tropical cyclone frequency has 1 rather than 2 distinct peaks in the distribution. For comparison, the climatological precipitation for the core of the MSD region (Fig. 3) is presented. Rainfall shows a pronounced bimodal distribution, reduced by roughly $40 \%$ in late July as compared to June and September. Also, the power of the $\mathrm{SOH}$ is twice as large as the power of the $\mathrm{FOH}$ ( $62.6 \%$ vs $31.3 \%$ of the variance). The MSD leads the August minimum in tropical cyclones.

As in Section 3, the number of tropical cyclones was divided into El Niño, La Niña, and Neutral composites. For the El Niño composite (Fig. 5B) the variance explained by $\mathrm{SOH}$ increased to $30.1 \%$, approaching the variance explained by the $\mathrm{FOH}(49.1 \%)$. Besides the local maximum in early August, the 2 peaks in the distribution occur in early July and late September. The sec- ond and larger peak is at the same time as the heaviest rainfall during an average El Niño summer. The summertime frequency of named storms during La Niña events (Fig. 5C) is not bimodal. Peaks in early July, late July, early August, and early September dominate the distribution. The MSD is also weak, as the early season precipitation maximum is not well defined. The first and second harmonics explain about equal amounts of the variance ( 40.5 vs $38.1 \%$ ) for the precipitation time series. For Neutral years (Fig. 5D) there is a weak bimodal signal in storm frequency and rainfall. The late season peaks are damped as compared to the ENSO composites. The total number of tropical cyclones for the El Niño, La Niña and Neutral years are 82, 80, and 75, respectively. These numbers are not significantly different, supporting the results of Whitney \& Hobgood (1997).

\section{SEA-SURFACE TEMPERATURES}

Magaña et al. (1999) show that SSTs decrease over the eastern Pacific warm pool in July or August in 


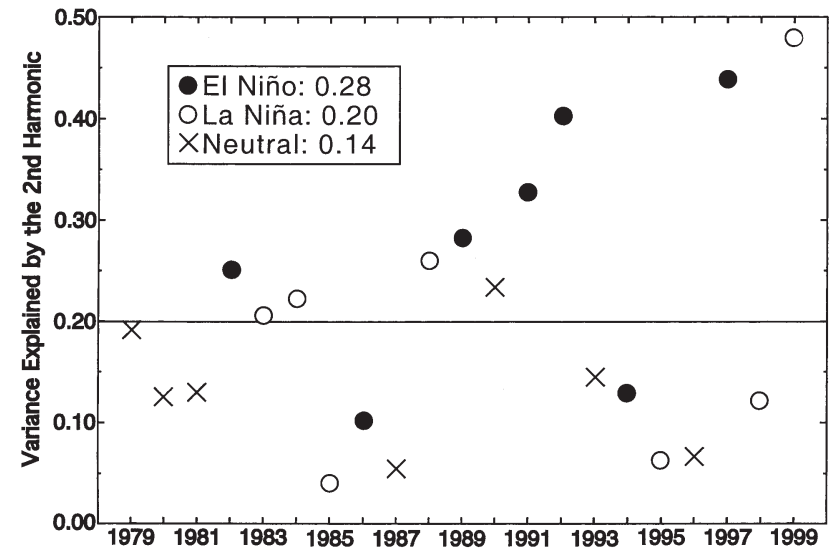

Fig. 4. Variance explained by the second-order harmonic for May-October precipitation averaged over the box in Fig. 3. Solid circles: El Niño years; open circles: La Niña years; crosses: Neutral years. The average variance explained for each category is given in the legend box

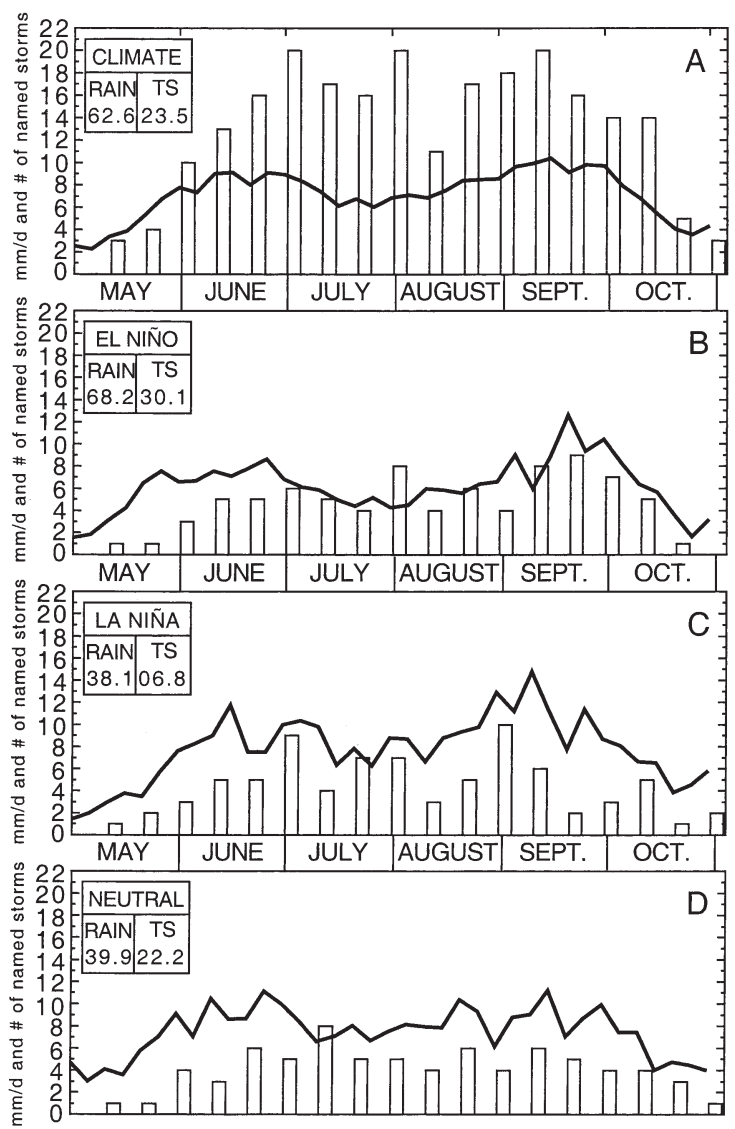

Fig. 5. May-October time series of precipitation averaged over the box in Fig. 3 (solid line) and number of named storms observed in the North Pacific east of $110^{\circ} \mathrm{W}$ (open bars). (A) 1979-1999 climatology, (B) El Niño years, (C) La Niña years, and (D) Neutral years. The variance explained (in hundredths) by the second-order harmonic for the rainfall (RAIN) and tropical storm (TS) time series are given in the upper lefthand corners response to increases in convective activity and changes in wind patterns. Here the same data (see Section 2) are examined, but separated into extreme wintertime ENSO events.

In the El Niño summer the waters are anomalously warm until late September, when there is a sudden return to normal conditions (Fig. 6A). The La Niña summer shows a slow decline in SST from June to October (Fig. 6B). Finally, observations during Neutral summers show the greatest resemblance to Magaña et al.'s (1999) 1982-1993 climatology. SSTs are high in June, briefly decline in July-August, and increase into September-October (Fig. 6C).

\section{DISCUSSION AND SUMMARY}

While wintertime ENSO is highly correlated with the previous June-August precipitation in the Mexican monsoon region (Table 1), there is no correlation at the beginning (May) and end (September) of the

A) 1982, 91, and 97 El Ninos

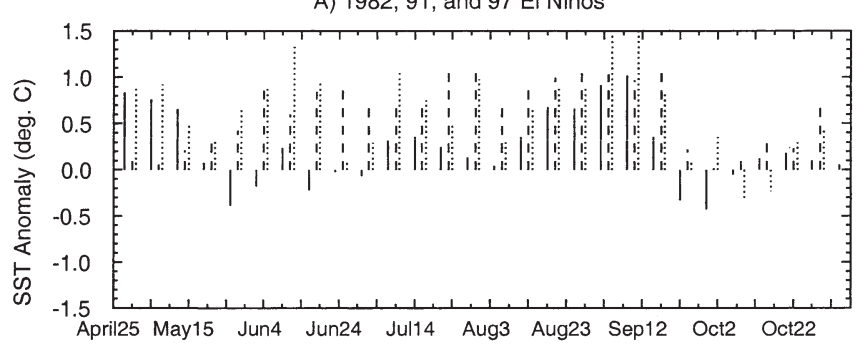

B) 1983, 95, and 99 La Ninas

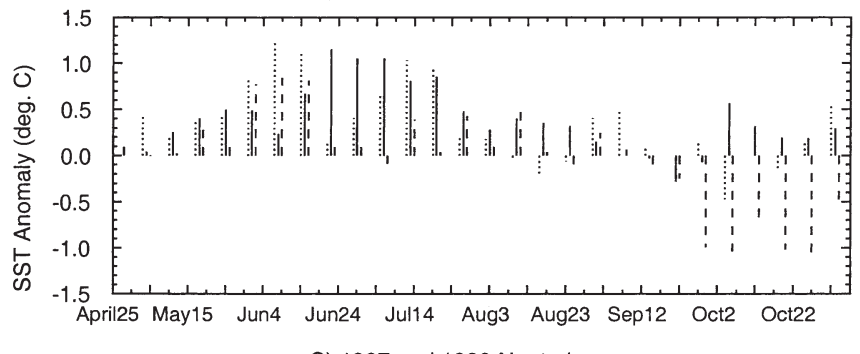

C) 1987 and 1990 Neutral

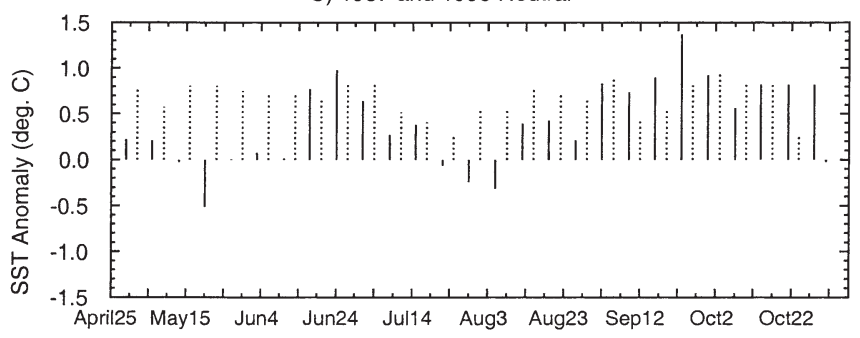

Fig. 6. The weekly sea-surface temperature (SST) anomaly averaged over the eastern Pacific warm pool $\left(10-15^{\circ} \mathrm{N}\right.$, $105-95^{\circ} \mathrm{W}$ ) for May-October. (A) Solid lines: 1982; dotted lines: 1991; dashed lines: 1997. (B) Solid lines: 1983; dotted lines: 1995; dashed lines: 1999. (C) Solid lines: 1987; dotted lines: 1990 
monsoon (0.05 and -0.01 , respectively). Thus, early during El Niño summers the waters warm and precipitation increases simultaneously, as described by Magaña et al. (1999). However, the mid-summer drought (MSD) and mid-summer minimum in tropical cyclone development appear despite continued high temperatures. These minima are likely responses to changes in the large-scale circulation. The El Niñoinduced drought in the region is strongest in the middle of the summer season (Table 1), when the convection associated with the ITCZ is weakest and furthest south (Curtis et al. 1999). In September the storms return along with enhanced rainfall, blocking incoming solar radiation and reducing the SST. The net effect is the strongest MSD, in terms of percent decrease in mid-summer rainfall, as compared to Neutral or La Niña years.

The beginning of a typical La Niña summer behaves the same way as an El Niño summer, but instead of heading southward, the ITCZ shifts northward, leading to a slow decline in SST and a small decrease in precipitation. Neither the rainfall nor the number of named storms shows an obvious mid-summer minimum. Irwin \& Davis (1999) found that more tropical cyclones originate and remain near the Mexican coast during La Niña. The end of the summer is also similar between El Niño and La Niña events. In September rainfall increases substantially, possibly tied to enhanced tropical cyclone activity. Sixteen named storms from August 29 to September 17 were identified during the 7 La Niña years studied (Fig. 5C). Again, the increase in clouds and rainfall diminishes the incoming solar radiation and cools the underlying waters.

Finally, observations during Neutral summers show the greatest resemblance to Magaña et al.'s (1999) proposed chain of causality for the MSD. Increasing precipitation during June leads to a drop in SST, consequently inhibiting rainfall in July-August and allowing increased solar radiation to warm the waters, which is followed by the return of precipitation in September. Magaña et al.'s (1999) dynamical explanation also involves changes to the surface convergence, which are not examined here.

In summary, the spectral peak in the second-order harmonic of boreal summer precipitation is uniquely strong over Pan America as compared to the rest of the world. An index of precipitation over Central America confirms that the second-order harmonic describes the MSD phenomenon for this region. The number of tropical storms originating east of $110^{\circ} \mathrm{W}$ also decreases in the middle of summer, but the second-order harmonic does not explain as much of the intraseasonal power as the first-order harmonic. Magaña et al. (1999) proposed local air-sea interactions in establishing the MSD. The findings presented here are consistent with this hypothesis for Neutral (non-El Niño and non-La Niña) summers. However, during El Niño and La Niña large-scale changes in circulation, namely the preferred location of the eastern Pacific ITCZ, are just as, if not more, important as local airsea mechanisms.

\section{LITERATURE CITED}

Adams DK, Comrie AC (1997) The North American monsoon. Bull Am Meteorol Soc 78:2197-2213

Bell GD, Halpert MS, Ropelewski CF, Kousky VE, Douglas AV, Schnell RC, Gelman ME (1999) Climate assessment for 1998. Bull Am Meteorol Soc 80:S1-S48

Curtis S, Adler R (2000) ENSO indices based on patterns of satellite derived precipitation. J Clim 13:2786-2793

Curtis S, Adler R, Huffman G, Bolvin D, Nelkin E (1999) Global precipitation patterns associated with ENSO and tropical circulations: ENSO and the summer monsoons over southern Asia and Mexico. Proc 24th Climate Diagnostics and Prediction Workshop, US Department of Commerce, Springfield, VA, p 142-144

Englehart PJ, Douglas AV (2001) The role of eastern North Pacific tropical storms in the rainfall climatology of western Mexico. Int J Climatol 21:1357-1370

Hartmann D (1993) Global physical climatology. Academic Press, New York

Higgins RW, Shi W (2001) Intercomparison of the principal modes of interannual variability of the North American Monsoon System. J Clim 14:403-417

Higgins RW, Chen Y, Douglas AV (1999) Interannual variability of the North American warm season precipitation regime. J Clim 12:653-680

Irwin RP, Davis RE (1999) The relationship between the Southern Oscillation Index and tropical cyclone tracks in the eastern North Pacific. Geophys Res Lett 26:2251-2254

Keables M (1989) A synoptic climatology of the bimodal precipitation distribution in the upper Midwest. J Clim 2: 1289-1294

Magaña V, Amador JA, Medina S (1999) The midsummer drought over Mexico and Central America. J Clim 12: 1577-1588

Maloney ED, Hartmann DL (2000) Modulation of eastern North Pacific hurricanes by the Madden-Julian Oscillation. J Clim 13:1451-1460

Reynolds R, Smith T (1994) Improved global sea surface temperature analyses using optimum interpolation. J Clim 7 : 929-948

Rodgers EB, Adler RF, Pierce HF (2000) Contribution of tropical cyclones to the North Pacific climatological rainfall as observed from satellites. J Appl Meteorol 39:1658-1678

Ropelewski CF, Halpert MS (1986) North American precipitation and temperature patterns associated with the El Niño/ Southern Osciallation (ENSO). Mon Weather Rev 114: 2352-2362

Whitney LD, Hobgood JS (1997) The relationship between sea surface temperatures and maximum intensities of tropical cyclones in the eastern North Pacific Ocean. J Clim 10:2921-2930

Xie P, Arkin PA (1997) Global precipitation: a 17-year monthly global analysis based on gauge observations, satellite estimates, and numerical model outputs. Bull Am Meteorol Soc 78:2539-2558 